\title{
MENGGALI PENGALAMAN MENGGUNAKAN TEKNOLOGI BERBASIS INTERNET DALAM MEMPERSIAPKAN INDONESIA MENUJU INDUSTRI 4.0
}

\section{DISCOVERING EXPERIENCES THROUGH THE APPLICATION OF INTERNET-BASED TECHNOLOGY IN PREPARING INDONESIA TOWARDS INDUSTRY 4.0}

\author{
Annisa Reginasari', Verdiantika Annisa ${ }^{2}$ \\ Universitas Gadjah Mada ${ }^{1-2}$ \\ J1. Humaniora No. 1 Bulaksumur, Yogyakarta 55281 \\ annisa.reginasari@mail.ugm.ac.id ${ }^{1}$, verdiantikaannisa@mail.ugm.ac.id ${ }^{2}$
}

Diterima: 9 Oktober 2018; dikembalikan untuk direvisi: 20 November 2018; disetujui:15 Desember 2018

\begin{abstract}
Abstrak
Tren penggunaan sistem digital berbasis internet merupakan salah satu karakteristik kehadiran era revolusi industri ke empat. Adanya kesenjangan digital khususnya di Indonesia menjadi permasalahan tersendiri. Penelitian ini dimaksudkan untuk menggali sejauhmana pengalaman partisipan terhadap penggunaan sistem digital berbasis internet di lingkungan kerja dan pendidikan; dan mengetahui harapan individu bagi pengembangan penggunaan sistem digital berbasis internet di masa yang akan datang. Penelitian ini menggunakan pendekatan kualitatif dengan metode fenomenologi yang fokus pada esensi pemahaman tentang pengalaman individu. Teknik pengumpulan data dengan wawancara mendalam kepada 2 orang partisipan dan jajak pendapat pertanyaan setengah terbuka (open-ended quesionnaire) kepada 41 orang partisipan baik di lingkungan kerja maupun instansi pendidikan. Hasil penelitian menunjukkan bahwa terdapat pengalaman positif dan negatif dalam menggunakan sistem digital berbasis internet. Kondisi ini dipengaruhi oleh besarnya keinginan menggunakan sistem digital berbasis internet yang tidak diingiri dengan optimalisasi penerapan sistem teknikal dan kemampuan dalam literasi digital.
\end{abstract}

Kata Kunci: kesiapan perubahan, literasi digital, industri 4.0

\begin{abstract}
The trend of the application of internet-based digital system is one of the characteristics of the emergence of the fourth industrial revolution era. The presence of digital gap especially in Indonesia has become a particular issue. This research is aimed to discover how far the experiences of participants regarding the utilization of internet-based digital system for in work and education environments; and to discover the hopes of individuals for future development of internet-based digital system. This research was using qualitative approach through phenomenological method which focused on the essence of understanding regarding individual experiences. Data were collected through depth interview towards 2 participants and open-ended questionnaire towards 41 participants either in work environment or educational institution. The research results have indicated that there are positive and negative experiences in the application of internet-based digital system. Positive experiences
\end{abstract}


occur from high benefits which acquired from the application of internet-based digital system. While negative experiences occur from the high desire to use internet-based digital system which not adjusted to the optimization of technical system implementation, the policy digital system application and the capability in digital literacy. These condition become the hope of individuals for internet-based digital system in the future.

Keywords: readiness for change, digital literacy, industry 4.0

\section{PENDAHULUAN}

Indonesia sedang mempersiapkan langkah strategis untuk menghadapi revolusi industri ke empat (Industrial revolution 4.0). Revolusi Industri 4.0 merupakan tren otomatisasi pertukaran data yang mementingkan peran internet untuk segala hal (internet of things). Kementerian Perindustrian Republik Indonesia mendorong perusahaan dan industri, baik yang berskala kecil maupun berskala nasional, agar mulai mempertimbangkan untuk menggunakan teknologi berbasis internet seperti e-smart, Big Data, Autonomous Robots, Cybersecurity, Cloud, dan Augmented Reality (Kementerian Perindustrian Republik Indonesia, 2018). Teknologi berbasis internet di bidang industri memungkinkan untuk memperluas rantai pemasaran ekspor, memacu produktivitas dan daya saing kerja, serta menaikkan efisiensi dengan mengurangi biaya produksi. Kebijakan tertentu harus diambil untuk menjamin kualitas angkatan kerja agar terampil menggunakan teknologi.

Dalam tujuan mendukung strategi kebijakan revolusi Industri ke empat, Kementerian Riset, Teknologi, dan Perguruan Tinggi (2018) mempersiapkan strategi kebijakan di bidang pendidikan untuk meningkatkan kualitas insan intelektual di dunia kerja melalui modifikasi kurikulum; peningkatkan kemampuan pemahaman tentang internet of things, Information
Technology, Operational Technology dan Big Data Analitic; pengintegrasikan objek fisik, digital dan manusia untuk menghasilkan lulusan perguruan tinggi yang kompetitif dan terampil terutama dalam literasi data, literasi teknologi, dan literasi manusia. Kebijakan publik yang bersifat integratif, lintas bidang pemangku kebijakan, bersifat transformatif, dan menyeluruh akan menghasilkan kualitas insan intelektual Indonesia yang siap menjadi generasi penggerak industri di masa yang akan datang.

Pada kenyataannya, strategi kebijakan pemerintah dalam menghadapi era digital masih terbentur dengan kesenjangan digital khususnya di negara berkembang. Di Malaysia, Judi, Ashaari, Zin, dan Yusof (2013) melaporkan adanya permasalahan yang mengkhawatirkan orang tua dan guru terhadap tren perilaku remaja yang menggunakan bantuan komputer berbasis internet di daerah rural. Di Indonesia, kesenjangan digital masih tergolong besar dengan nilai indeks digital divide tertinggi di daerah Indonesia Bagian Timur dan Indonesia Bagian Tengah (Ariyanti, 2013). Faktor lokasi geografis dan sosial-ekonomi berperan dalam mempengaruhi interaksi permasalahan ketersediaan akses informasi yang memadai (Puspitasari \& Ishii, 2016; Syarifuddin, 2014). Sebanyak 72\% akses internet digunakan oleh penduduk yang tinggal di daerah urban (GDP berasal dari sektor non 
pertanian), hanya $48 \%$ akses internet oleh pengguna di daerah sub-urban/rural (GDP berasal dari sektor pertanian); dan mayoritas pengguna akses internet masih terkonsentrasi di pulau Jawa (Asosiasi Penyelenggara Jasa Internet Indonesia dan Teknopreneur, 2017).

Selain tantangan dalam pemerataan penetrasi teknologi di seluruh wilayah, tentunya kapabilitas angkatan kerja di lingkungan serba-digital melibatkan proses belajar yang bertahap dan berkelanjutan sepanjang hayat(Van Aalst, Hing, May, \& Yan, 2007). Individu perlu belajar bagaimana cara mengumpulkan, mengevaluasi, menciptakan kembali, dan menampilkan informasi dari dan kepada suatu medium digital berbasis internet. Rangkaian kemampuan ini dikenal dengan literasi informasi digital; atau sering disebut dengan literasi media digital (Park, 2012; Syarifuddin, 2014; Takenouchi, 2004).

Kecanggihan teknologi telah mengubah dinamika organisasi dan dunia kerja dalam perubahan pada protokol dan cara memproses pekerjaan (Flood, 2016). Peran jejaring media sosial di bidang kajian-kajian psikologi industri menjadi penting untuk meningkatkan kepuasan konsumen (Hanaysha, 2017); dan membantu pengembangan sumber daya manusia profesional dalam organisasi untuk membangun pembelajaran di tempat kerja dan strategi pengelolaan pengetahuan (Thomas \& Akdere, 2013). Studi kali ini mengadopsi Teori Perubahan Organisasi dari Kurt Lewin (Cummings \& Worley, 2008; Kreitner \& Kinichi, 2007) untuk menerangkan bagaimana teknologi digital berbasis internet mengantarai perubahan dalam organisasi (instansi pendidikan dipandang dalam sudut pandang organisasi) yang kemudian berdampak pada kinerja individu yang berada di dalam sistemnya.

Penerapankebijakan sistem digital berbasis internet di lingkungan industri dan pendidikan perlu mempertimbangkan keadaan literasi informasi penggunanya. Hal ini menjadi penting karena persoalan pengoperasian perangkat digital berbasis internet jauh lebih rumit dan lebih menuntut keterampilan dari penggunanya (Park, 2012). Kemampuan pemerolehan informasi digital yang dimiliki seseorang perlu ditinjau dan dipahami sesuai dengan kategori, bidang, tingkatan, lapisan, serta tujuan penggunaannya (Park, 2012; Puspitasari \& Ishii, 2016; Syarifuddin, 2014; Takenouchi, 2004).

Berdasarkan kategori, (dimulai dari yang khusus kepada yang umum) literasi informasi terbagi menjadi tiga yakni, literasi informasi mekanik, literasi sosial, dan literasi kehidupan Takenouchi, 2004). Literasi informasi mekanik merupakan kemampuan untuk mengoperasikan mesin pemeroses informasi (literasi komputer); literasi informasi sosial merupakan kemampuan untuk membaca dan memahami makna informasi yang diekspresikan dan dibagikan orang lain secara eksplisit (literasi media); dan literasi informasi hidup merupakan kemampuan komunikasi untuk memahami makna yang disampaikan oleh orang lain, terkait budaya, dan pola-pola yang dipelajari dan dibagikan bersama di masyarakat. Informasi yang dibutuhkan akan lebih mudah dikelompokkan berdasarkan bidang keilmuan atau posisi pengguna, misalnya informasi yang dicari oleh pelajar digunakan untuk menyelesaikan tugas, sedangkan informasi yang dibutuhkan untuk pebisnis digunakan untuk melengkapi pekerjaan yang diberikan oleh perusahaan atau organisasi. 
Senada dengan konsep literasi mekanik Takenouchi (2004), Puspitasari dan Ishii (2016) dan Syarifuddin (2014) memandang bahwa literasi informasi digital merupakan tingkatan bertahap (hierarkis) dalam identifikasi kepemilikian, berlangganan layanan internet, hingga pada penggunaan perangkat digital dan internet dalam pemerolehan informasi. Bagian dimensi literasi informasi yang diberikan Park (2012) menyoroti kemampuan pencipta konten media internet yang peka terhadap etiket dan etika dunia siber mirip dengan komponen literasi informasi hidup karena menuntutkepekaan individu dalam memahami budaya dan nilai-nilai dalam kehidupan masyarakat. Oleh karena literasi informasi digital media dipandang sebagai sebuah konsep yang multi dimensi dan berjenjang, maka diperlukan proses yang bertahap untuk mencapai kemampuan literasi informasi digital individu yang paling optimal. Literasi informasi media digital berbasis internet setidaknya dimulai dari pemahaman teknis-mekanis, kemudian kemampuan untuk menciptakan dan mendapatkan informasi, hingga pada tahap tertinggi adalah kesadaran akan dampak informasi yang diperoleh-diciptakan terhadap aspek sosial, budaya, dan etika sehari-hari.

Literasi digital memiliki dampak positif terhadap kecakapan yang esensial untuk pembelajaran dalam lingkungan teknologi digital (Alvermann, 2004; Judi et al., 2013). Perusahaan membutuhkan karyawan untuk mengaplikasikan Teknologi Komunikasi dan Informasi dalam lingkungan kerja untuk komunikasi, pembagian informasi, dan simulasi untuk proses-proses dalam kegiatan bisnis (Techataweewan \& Prasertsin, 2018). Pelajar yang tidak memiliki kekuatan literasi digital akan menghadapi pencapaian akademik yang buruk dan lebih sedikit mendapatkan peluang kerja. Khususnya pada mahasiswa, peluang menjadi calon pekerja memerlukan tak hanya pengetahuan yang mumpuni, tetapi juga keterampilan dalam penguasaan teknologi untuk menjamin kinerja dilakukan secara efektif (Techataweewan \& Prasertsin, 2018). Individu yang memiliki keahlian dasar sebagi pengguna digital dapat mempergunakan keahliannya untuk mengatur rencana karir berdasarkan pengalaman penggunaan media digital di konteks pendidikan dan di rumah (Gurung \& Rutledge, 2014). Tantangan bagi universitas masa kini adalah untuk mengaitkan literasi digital dalam sistem pendidikan. Oleh karenanya, literasi digital merupakan sebuah elemen yang penting untuk diperhatikan instansi pendidikan tinggi untuk mendukung peningkatan kualitas insan intelektual di dunia industri dan organisasi.

Adapun pertanyaan penelitian yang diajukan adalah (a) Bagaimana pengalaman menggunakan sistem digital berbasis internet di tempat kerja atau kuliah?; (b) Bagaimana harapan untuk sistem digital berbasis internet di masa yang akan datang? Adapum tujuan dari penelitian ini adalah untuk menggali pengalaman yang dialami partisipan dalam menggunakan sistem digital berbasis internet sekaligus mengetahui harapan partisipan terhadap sistem digital di masa yang akan datang. Peneliti ingin mengeksplorasi sejauh mana kondisi penerapan sistem digital yang ada di lingkungan kerja atau di lingkungan belajar para partisipan, maupun respon individu yang berinteraksi dengan media digital dalam lingkungan tersebut. Penelitian ini diharapkan dapat memberikan informasi 
bagi penyusun kebijakan pendidikan dan kebijakan industri untuk mempertimbangkan dan mengevaluasi penerapan sistem digital berbasis internet.

\section{METODE}

Penelitian ini menggunakan pendekatan Kualitatif dengan metode pendalaman Fenomemologi dimana peneliti berusaha memahami tentang pengalaman subjektif individu (La Kahija, 2017). Teknik pengumpulan data yang digunakan adalah wawancara dan jajak pendapat pertanyaan setengah terbuka (open-ended quesionere) yang dilakukan dengan bantuan sambungan telepon dan layanan perangkat survei daring google.form. Halaman virtual untuk menyatakan persetujuan telah dilengkapi para partisipan penelitian sesuai dengan aturan kode etika penelitian.

Adapun populasi penelitian adalah warga negara Indonesia yang menggunakan sistem digital berbasis internet dalam proses kerja dan belajar. Teknik sampel berdasarkan sampling purposif dimana peneliti menentukan karakteristik atau ciri-ciri yang sesuai dengan tujuan penelitian (Glaser \& Strauss, 1967). Adapun karakteristik sampel yang diterapkan dalam penelitian ini adalah individu yang berstatus sebagai pekerja atau pelajar di salah satu perusahaan, organisasi atau instansi pendidikan, dimana individu tersebut menggunakan sistem teknologi berbasis internet dalam proses bekerja atau belajar.

Peneliti melakukan triangulasi metode yakni survei dan wawancara; serta melakukan member-checking pada partisipan wawancara untuk menjaga kredibilitas hasil penelitian. Proses pengumpulan data dan triangulasi dilakukan selama 1 bulan, dari tanggal 18 Agustus - 20 September 2018. Analisis isi data survei kualitatif dan transkrip wawancara dilakukan dengan pengkodean respon, sub-tema, dan menyimpulkan tema-tema sesuai dengan jawaban yang dituliskan para partisipan dalam lembar respon. Deskripsi informasi disajikan dalam bantuan grafik dan diagram.

Partisipan yang bergabung dalam survei diminta untuk melengkapi informasi diri, termasuk nomor telepon yang dapat dihubungi dan/atau alamat surel. Ada 41 partisipan (66\% perempuan; usia 21-37 tahun) yang bersedia menuliskan jawaban dalam survei pertanyaan setengah terbuka. Partisipan survei berasal dari beberapa daerah di Indonesia seperti Kabupaten Bantul dan Sleman (Yogyakarta), Solo (Jawa Tengah), Kota Bontang (Kalimantan Timur); Jambi, Kota Pasuruan (Jawa Timur), dan Kabupaten Indragiri Hilir (Riau). Para partisipan berstatus sebagai karyawan (39\%), mahasiswa $(24,4 \%)$, wiraswasta $(17,1 \%)$, guru $(4,9 \%)$, aparat sipil negara $(4,9 \%)$, dan selainnya adalah sebagai dosen, terapis, dan pekerja lepas.

Dua partisipan bersedia untuk diwawancara dalam penelitian ini. Partisipan NAK adalah seorang perempuan berusia 26 tahun; ahli psikologi yang bekerja pada sebuah perusahaan Konsultan IT (Informasi dan Telekomunikasi) sebagai tim ahli yang bertanggung jawab dalam perekrutan pegawai di perusahaan. Partisipan kedua yakni PTR; seorang perempuan berusia 22 tahun yang bekerja sebagai karyawan di salah satu instansi pendidikan, dimana instansi tersebut mengoptimalkan penggunaan IT dalam proses kerja dan belajar-mengajar. 


\section{HASIL DAN PEMBAHASAN}

\section{Hasil Penelitian}

Deskripsi Respon Partisipan terhadap perangkat digital berbasis internet

Hasil perhitungan frekuensi penggunaan perangkat keras (Grafik 1) menunjukkan bahwa telepon seluler atau telepon pintar adalah perangkat yang paling banyak digunakan. Mayoritas partisipan menggunakan mesin Pencarian Google.com untuk mengakses informasi, di samping itu, untuk platform media sosial, Instagram lebih banyak diakses, dan Whastapp menjadi aplikasi pesan instan yang diminati (Grafik 2).

Sebanyak 78\% partisipan mengakui bahwa lingkungan kerja dan lingkungan sekolah/ kampus telah menerapkan kebijakan sistem digital berbasis internet (Diagram 1).

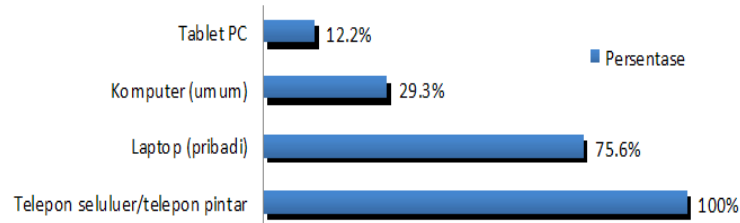

Grafik 1. Perangkat keras yang digunakan untuk mengakses internet

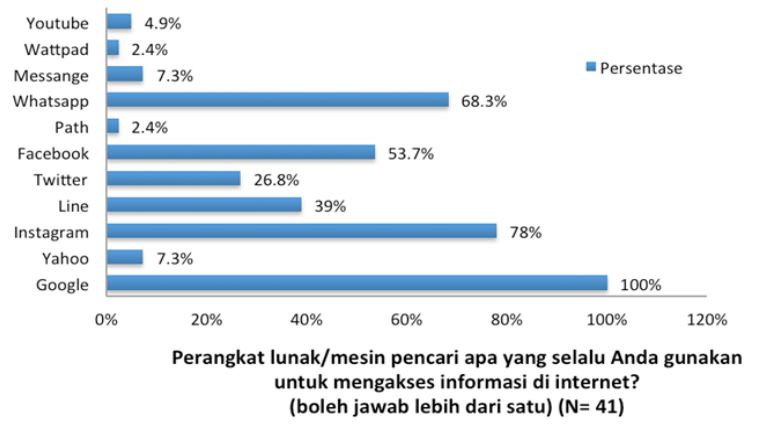

Grafik 2. Perangkat lunak yang digunakan untuk mengakses informasi di internet

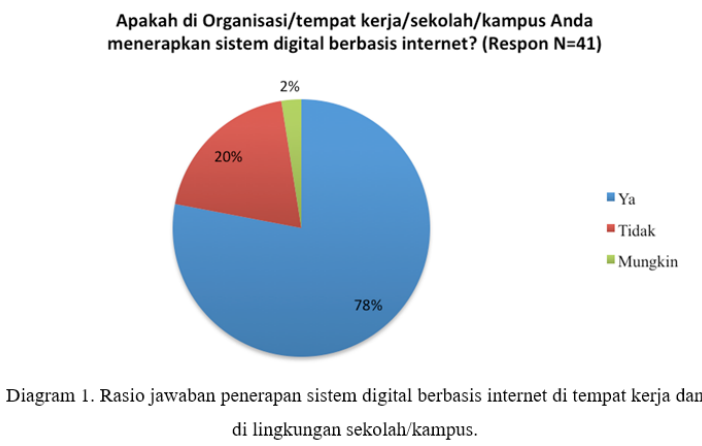

Hasil tematik dirumuskan berdasarkan respon para partisipan penelitian terhadap dua pertanyaan survei dan transkrip wawancara. Secara umum terungkap pada unsur (a) pengalaman positif dan pengalaman negatif yang dirasakan para partisipan dalam menggunakan sistem digital berbasis internet di tempat kerja atau di lingkungan kampus. Pengalaman positif yang dirasakan mencakup pengungkapan bahwa internet dapat mempermudah pebisnis, karyawan, dan pengajar untuk mengelola pekerjaannya dengan efektif, efisien, praktis, terintergrasikoordinasi.

“...karena tim yg mengerjakan project kadang bersama-sama dengan tim lain baik sesama kantor atau dengan kantor di luar negeri, maka kami menggunakan skype sebagai platform komunikasi utama. Pun dalam mengerjakan project kami banyak menggunakan aplikasi khusus untuk intern kantor serta memanfaatkan google docs" (P14, survei, 1)

"Menurut saya internet sangat membantu saya dalam bekerja terutama sebagai guru untuk mencari contoh contoh media pembelajaran dan penerapan materi" (P16, survei, 1)

Internet juga mendukung kesempatan membuka peluang kerja tambahan atau peluang kerja baru karena cara kerja yang fleksibel.

"...karena tim yg mengerjakan project kadang bersama-sama dengan tim lain baik sesama kantor atau dengan kantor di luar negeri, maka kami menggunakan skype sebagai platform komunikasi utama. Pun dalam mengerjakan project kami banyak menggunakan aplikasi khusus untuk intern kantor serta memanfaatkan google docs" (P14, survei,1)

"Menurut saya internet sangat membantu saya dalam bekerja terutama sebagai guru untuk mencari contoh contoh media pembelajaran dan penerapan materi" (P16, survei, 1) 
Internet juga diakses untuk memenuhi kebutuhan rekreasi, keinginan untuk berkarya, menemukan sumber hiburan untuk membuat suasana hati menjadi positif dan memberikan kepuasan penggunanya.

“...membuat peluang usaha dimana pun dan kapan pun tanpa harus menyediakan tempat usaha dan waktu, seperti saya disela bekerja dikantor ataupun malam hari saat istirahat saya sebagai agen travel online, konsumen bisa memesan tiket via telpo dg menggunakan aplikasi travel agen, pembayaran tinggal transfer dan tiket cukup via email atau whatshap, sungguh sangat membantu karena sebagai karyawan full bekerja tapi bisa bekerja sampingan dengan memanfaatkan sistem digital ini" (P5, survei, 1)

Partisipan melaporkan pengalaman yang menyenangkan saat sistem digital di kampus mereka sudah berbasis internet

"Sangat bagus, kecepatan internet di kampus saya sudah tergolong sangat cepat, selain itu akses jurnal yg banyak juga tersedia, dan hampir segala keperluan kampus bisa dilakukan via internet, misalnya Pesan surat, isi KRS, melihat jadwal" (P13, survei, 1)

Sistem internet bahkan sudah menjadi bagian dari hidup dan kebutuhan hidup sejak awal partisipan mengenal teknologi digital.

"Saya mengenal internet sejak dibangku SMP mulai dari warnet, mungkin sekitar tahun 2006 sampai saat ini tak pernah lepas darinya” (P18, survei 1)

Meskipun pengalaman positif diakui telah dirasakan para partisipan, pengalaman negatif dalam berinteraksi dengan sistem digital berbasis internet tampaknya tidak bisa dihindari. Pengalaman negatif diceritakan partisipan karena rendahnya kontrol keamanan informasi di media internet, sistem teknologi internet yang belum tersebar merata di seluruh wilayah, rendahnya kesiapan penerapan sistem berbasis internet, dan penggunaan yang berlebihan berpotensi membuat hidup menjadi kurang produktif. "kalo pas lemot [jaringan lambat] agak susah di pake apelagi di Papua masih sering jaringan hilang, jaringan disini GSM geser sedikit mati" (P25, survei, 1) “...Sistem pengarsipan surat jg menggunakan sistem digital. Namun sistem sering eror atau malah pihak tujuan surat tdk membuka sistem sesuai petunjuk. sehingga sering tdk efisien dan kembali ke cara konvensional" (P31, survei, 1)

(b) peningkatan kualitas,kecanggihan, dan efisiensi teknologi berbasis internet;

Peningkatan kualitas jaringan internet yang diharapkan berfokus pada jaringan yang lebih cepat, stabil, berbiaya murah, dan mampu menjangkau lebih luas ke seluruh wilayah Indonesia (terluar, terdepan, dan terpencil). Kecanggihan teknologi diharapkan menuju pada pengembangan sistem perangkat lunak yang mengutamakan langkah praktis, semakin sederhana, dan semakin terintegrasi. Berharap bahwa sistem digital mendatang lebih bisa digunakan secara bijak, baik di kalangan orang dewasa maupun anak. Dan mampu menampilkan atau memberikan informasi yg lebih layak utk dikonsumsi masyarakat luas. (24)

Diharapkan dimasa yang akan datang, biaya untuk mengakses internet tidak terlalu mahal dan kecepatan dalam mengakses internet juga lebih cepat terutama untuk kota-kota kecil ataupun terpencil $(26 ; 19,18)$

(c) Penggunaan teknologi dengan bijak dalam penerapan sistem teknologi digital

Partisipan penelitian menyadari pentingnya perilaku berinternet dengan bijak, kesiapan penerapan teknologi, dan 
isu keamanan internet. Partisipan berharap di masa mendatang, media internet dapat dioptimalkan untuk menjadi sarana yang lebih positif, sehingga pengguna lebih mampu memilah informasi yang layak dan sesuai dengan bidang kebutuhan, serta mengutamakan memelihara nilai-nilai kesopanan di dunia siber. Isu keamanan dalam berinternet yang perlu disoroti adalah tentang kewaspadaan penyerapan data pribadi dan adanya pengawasan dari pemerintah. Kesiapan penerapan sistem digital diharapkan dengan sosialisasi ke seluruh pihak untuk dapat memecahkan kesulitan-kesulitan yang lebih spesifik.

"Mungkin sebaiknya Tidak menyerap data pribadi mahasiswa dan dosen tanpa izin karena sistem anti virus kaspersky saya menyatakan bahwa area wifii tidak aman sehingga mungkin dapat dimatamatai data2 pribadi kita" (P8, survei, 1)

Literasi digital dipandang sebagai sejauh mana manusia mampu menguasai teknologi dengan bijak. Manusia dipandang sebagai penentu caranya sendiri dalam penggunaan digital

"distraksi atau tidaknya teknologi kembali lagi ke penggunanya apakah menggunakan dengan bijak" (NAK, 397403, waw)

Partisipan telah sampai pada pemahaman bahwa penggunaan media teknologi di satu sisi dapat memberi dampak negatif dalam pekerjaan, tetapi akan menguntungkan organisasi bila dimanfaatkan dengan tepat tergantung pada konten dan aktivitas di dalamnya. Salah satunya penggunaan media sosial yang seringkali berdampak buruk pada produktifitas di tempat kerja partisipan.

"ketika tidak pintar atau lupa utk mengatur waktu penggunaannya maka akan jadi berlebihan dan bisa dibilang lupa waktu untuk lakuin aktivitas yg lebih produktif' (P24, Survei, 1)

Harapannya, individu yang ada di dalamnya, bisa memberi nilai lebih bagi organisasi dalam mempromosikan instansi pendidikan ke masyarakat melalui sosial media.

"Lewat medsos kan bisa kita share kita kerja apa, terus ngapain aja kerjaannya. Nah itu kan bisa memotivasi orang atau bahkan mempromosikan tempat kerja kita, pekerjaan kita, budaya kerja kita yang baik. Sehingga kalo di kampus, makin banyak mahasiswa yang mau masuk. Kita tonjolkan kita sebagai pekerja di sini ramah-ramah. Dekat dengan mahasiswa. Kan itu nanti bisa jadi keuntungan bagi kampus.Ya jadi intinya tergantung kontennya sih dan aktivitasnya" (PTR, 176-182, waw).

(d) kebijakan yang mendukung penggunaan sistem teknologi digital yang memenuhi kebutuhan karyawan

Pemangku kebijakan di lingkungan organisasi/industri perlu memahami gaya berpikir dan perilaku kerja yang berbeda antara karyawan angkatan muda dengan karyawan angkatan tua. Berkaca pada generation theory (teori generasi), Benchick dan Machova (2016), mengungkapkan bahwa terdapat perbedaan gaya kerja antar generasi sesuai dengan kedekatannya pada teknologi. Kondisi ini mempengaruhi perbedaan cara berpikir dan berperilaku dalam bekerja terutama ketika menghadapi perubahan dan ketidakpastian. Karyawan angkatan tua, yang biasa disebut generasi $\mathrm{X}$ dan generasi sebelumnya cenderung lebih banyak bertahan dalam pekerjaan dan sulit mengikuti proses perubahan dengan cepat dibandingkan pekerja muda (Cran, 2010). Hal ini senada 
dengan ungkapan partisipan berikut:

“...sistem integrasi [berbasis-internet] itu harus diikuti dengan pelatihan juga. Karna kan gak semua di sini karyawannya muda, ada juga yang udah tua" (PTR, 202-203)

"angkatan yang kayak '80 kayak gitu tu biasanya mereka akan lebih stay lah, lebih stabil di satu company gitu (NAK, 122-123)

Angkatan kerja muda bekerja dengan cara yang khas seperti memiliki kemampuan pemecahan masalah yang out of the box, lebih cepat belajar dan cepat menyesuaikan diri dengan perubahan, lebih kompetitif, dan eksploratif. Hal ini sejalan dengan temuan penelitian Elmore (2014) bahwa generasi pekerja muda termasuk individu yang fleksibel, optimis dan ambisius dalam bekerja. Hal ini karena angkatan kerja muda lebih familier dengan teknologi digital berbasis internet, maka mereka cenderung suka pekerjaan yang fleksibel, variatif dan penuh tantangan.

"staf junior punya kemampuan eksplorasi terhadap perkembangan IT terbaru level junior lebih suka banyak mengulik (eksplorasi) tentang bahasa pemprograman yang cocok dan terbaru (NAK, 349-356)

"Generasimilenial lebih kreatif dan kompetitif” (NAK 331-332)

"kalau misalnya ada satu assignment atau task yang itu sebenarnya melenceng dari apa yang harusnya dikerjakan, mereka berani protes dan kadang berani juga buat langsung cabut [mundur] gitu dari company, terus akhirnya cari lagi [perusahaan] yang lain Jarang ada generasi milenial ibaratnya yang bisa struggle di 2 tahun. Kayak ada yang baru 6 bulan itu tu sudah pindah... karena [memang] sekarang company-company kan lebih bervariatif dan challenging yang mereka kasih juga lebih banyak. Akhirnya generasi-generasi milenial itu lebih banyak pilihan"'(NAK, 111-128)

Dalam lingkungan pendidikan, penggunaan teknologi berbasis internet mendorong perubahan sistem dan proses kerja khususnya dalam kegiatan belajarmengajar.

...dosen juga bisa mengupload materi yang nanti bisa di download oleh mahasiswa. Bahkan bisa kuliah secara online kalo emang mahasiswa kan kebanyakan emang udah kerja, jadi bisa secara online. Melakukan tanya jawab secara berkala secara online (WA). Bahkan ketika waktu kerja, sehingga bisa bersifat praktikal pembelajarannya dari kasus-kasus nyata perusahaan mereka masing-masing. (PTR, 209-217)

Karena generasi angkatan kerja muda lebih menyukai pekerjaan yang fleksibel, variatif dan penuh tantangan, maka perusahaan perlu membuat kebijakan perusahaan tentang penggunaan teknologi digital berbasis internet yang menyesuaikan dengan karakter angkatan kerja muda.Perusahaan industri kreatif perlu memberikan lebih banyak tantangan dan tawaran yang menarik bagi karyawan angkatan muda.

Penciptaan dan pengembangan aplikasi digital oleh kreator perusahaan bidang IT hendaknya dilakukan dengan mempertimbangkan tujuannya untuk mempermudah proses kinerja dan kebutuhan manusia sehari-hari.

“...Kreator memang dari bidang IT, tapi pengguna dan penikmat digital itu seтиa orang” (NAK, 385-387)

Kebijakan di perusahaan maupun di lingkungan pendidikan perlu memenuhi kebutuhan pelatihan dan evaluasi lebih lanjut 
sehingga penerapan sistem teknologi digital ini bisa diikuti oleh seluruh karyawan.

"...sistem integrasi [berbasis-internet] itu harus diikuti dengan pelatihan juga. Karna kan gak semua di sini karyawannya muda, ada juga yang udah tua" (PTR, 202-203)

\section{PEMBAHASAN}

Penelitian ini bertujuan untuk menggali pengalaman yang dialami partisipan dalam menggunakan sistem digital dan mengetahui harapan partisipan terhadap media digital di masa yang akan datang. Penelitian penggunaan media digital di Indonesia telah menarik minat peneliti lintas bidang keilmuan untuk mendeteksi pola-pola aktivitas yang mendasarinya (Puspitasari \& Ishii, 2016; Ramdhani \& Wiradhany, 2013; Syarifuddin, 2014). Para partisipan penelitian kali ini menggunakan telepon seluler-pintar sebagai pilihan perangkat keras dan media sosial Instagram sebagai perangkat lunak yang sering digunakan dalam kesehariannya. Penemuan menegaskan bahwa bahwa partisipan terlibat interaksi dengan media digital dalam pilihan perangkat keras dan perangkat lunak tertentu untuk dapat terhubung dengan orang lain (Reginasari dalam Afiatin, Sudibyo, \& Reginasari, 2018; Wahid, Ramdhani, \& Wiradhany, 2013).

Mayoritas para partisipan mengakui bahwa lingkungan kerja dan lingkungan belajar mereka telah menerapkan sistem digital berbasis internet. Penemuan ini penting menjadi perhatian bahwa kebijakan pemerintah di bidang industri-organisasi dan pendidikan sudah dilaksanakan dalam tataran implikasi. Hasil ini sejalan dengan penemuan Syarifuddin (2014) dalam studinya pada masyarakat Sulawesi Selatan, bahwa mayoritas masyarakat sudah sampai pada tahap lima (tahap tertinggi) pada media teknologi, namun pada media internet rata-rata literasi media masih berada pada tahap tiga karena ada faktor keterbatasan infrastruktur dan jaringan yang kurang memadai.

Secara garis besar, pengalaman menggunakan sistem digital berbasis internet di lingkungan kerja dan pendidikan dimaknai dengan dua sisi, positif dan negatif. Banyak faktor dari temuan penelitian ini sehingga pengalaman dua sisi ini muncul. Pengalaman campuran yang dirasakan partisipan penelitian kali ini sejalan dengan penemuan Gurung dan Rutledge (2014) yang menemukan bahwa ada pengalaman tumpang-tindih yang dirasakan pengguna media digital saat mengakses informasi untuk kepentingan performa tugas dengan kepentingan akses keseharian (seperti kebiasaan-kebiasaan dan preferensi pribadi). Tumpang-tindih pengalaman ini dapat berimplikasi pada kondisi paradoks penggunaan media digital yang dapat memfasilitasi kinerja dan secara bersamaan dapat mengganggu kinerja. Gurung dan Rutledge (2014) menyarankan perlunya keselarasan kapasitas penggunaan digital oleh individu antara konteks kehidupan pribadi dan aspek lainnya.

Secara teknis partisipan pada penelitian kali ini mengetahui dan mampu mengoperasikan secara mekanistik perangkat lunak dan kasar dari sistem digital berbasis internet. Dari kemampuan tersebut, partisipan kemudian merasakan pengalaman positif dari penggunaan sistem digital berbasis internet seperti kemudahan, fleksibilitas, dam efisiensi. Kondisi ini kemudian memotivasi partisipan untuk belajar lebih jauh dan memanfaatkan media teknologi seoptimal 
mungkin.

Hanya saja kondisi ini tidak diimbangi dengan faktor-faktor penting dalam menunjang penggunaan teknologi. Seperti pada temuan penelitian ini masih ada masalah pada penerapan teknikal sistem yang belum optimal (stabilitas konektivitas jaringan), lemahnya kebijakan yang mendukung penggunaan sistem digital pada generasi angkatan kerja tertentu (karyawan senior vs junior) di lingkup kerja dan pendidikan. Sehingga dari faktor tersebut, kemudian partisipan memaknai pengalaman menggunakan sistem digital berbasis internet menjadi pengalaman yang negatif.

Penerapan media teknologi dapat dipahami dari sudut pandang Teori Perubahan Organisasi dalam menanggapi kesiapan individu menghadapi dunia digital. Lingkungan selalu berubah dengan cepat, apabila perubahan dapat dikelola dengan baik maka akan menjadi strategi bisnis yang efektif (Cummings \& Worley, 2008). Sama halnya dengan tren percepatan media teknologi digital berbasis internet sebagai salah satu bentuk loncatan perubahan yang harus disikapi dengan bijak.

Dalam prosesnyamemang perubahantidak serta merta bisa diikuti dengan mudah. Kurt Lewin (dalam Kreitner dan Kinichi, 2007) mengungkapkan bahwa pada lingkungan organisasi terdapat 3 tahapan penting dalam perubahan yakni 1) unfreezing, 2) changing dan 3) refreezing. Pada tahap unfreezing, perubahan memang masih sulit diterima. Seperti pada temuan penelitian ini bahwa karakteristik generasi di lingkungan kerja dan pendidikan mempengaruhi kecepatan organisasi untuk berubah. Generasi pekerja muda lebih cepat menyesuaikan diri terhadap perubahan terutama dalam bidang teknologi digital dibandingkan generasi pekerja tua (Cran, 2010). Sehingga perlu taktik dan kebijakan strategis untuk mengurangi resistance to change pada generasi pekerja tua untuk meninggalkan kebiasaan-kebiasaan lama (konvensional).

Pada tahap changing dibutuhkan keterampilan individu mempelajari pengetahuan, perilaku dan sistem yang baru. Peran literasi digital menjadi sangat penting pada tahap ini. Literasi digital yang dimiliki individu merupakan faktor yang penting dalam memfasilitasi kinerja dalam interaksi digital di tempat kerja (Mohammadyari \& Singh, 2015). Dalam literasi digital, individu perlu belajar bagaimana cara mengumpulkan, mengevaluasi, menciptakan kembali, dan menampilkan informasi dari dan kepada suatu medium digital berbasis internet (Park, 2012; Syarifuddin, 2014; Takenouchi, 2004). Organisasi perlu memfasilitasi individu yang ada di dalamnya dalam mempelajari sistem digital berbasis internet secara lebih mendalam dan bijak.

Terakhir yakni reefrezing, dimana perubahan yang telah dilakukan perlu diberi penguatan baik dalam bentuk umpan balik atau reward (penghargaan). Umpan balik dan reward diberikan apabila perilaku yang diharapkan muncul. Misal seperti partisipan dalam penelitian ini yang mampu mengoptimalkan penggunaan aplikasi sosial media untuk kebutuhan mempromosikan instansi pendidikannya, tentunya harus ada tindak lanjut dari organisasi untuk memberikan pengalaman respon positif agar perilaku penggunaan digital berbasis internet tersebut tetap bertahan. Oleh karena itu, perlu kebijakan dari pemerintah, organisasi maupun 
instansi pendidikan untuk menciptakan iklim organisasi pembelajaran yang tanggap akan perubahan terutama di era digital seperti saat ini.

\section{SIMPULAN DAN SARAN}

\section{Simpulan}

Terdapat pengalaman positif dan negatif dalam penerapan sistem digital berbasis internet baik di lingkungan kerja maupun pendidikan. Pengalaman positif timbul dari keuntungan yang dirasakan selama menggunakan internet dalam proses kerja dan belajar. Adapun pengalaman negatif muncul dari tingginya keinginan untuk menggunakan sistem digital berbasis internet tetapi tidak didukung dengan sistem teknikal yang optimal. Selain itu, rendahnya kemampuan literasi digital menyebabkan permasalahan performansi individu. Berdasarkan pengalaman tersebut, harapan individu terkait sistem digital berbasis internet dimasa yang akan datang perlu memiliki kualitas, kecanggihan, dan daya efisiensi yang lebih baik. Selain itu, individu perlu meningkatkan kemampuan literasi digital dengan didukung kebijakan penggunaan sistem teknologi digital, baik di lingkungan kerja maupun konteks pembelajaran. Tinggi atau rendahnya kemampuan literasi digital dapat dipengaruhi oleh kebijakan yang mempertimbangkan faktor demografis dan interaksi familieritasnya dengan teknologi digital.

\section{Saran}

\section{Bagi pemerintah}

Memberikan perhatian terhadap pemerataan kualitas teknis teknologi berbasis internet (seperti stabilitas sambungan internet) untuk mengurangi kesenjangan digital, khususnya pada daerah 3T di Indonesia. Pemerintah perlu memberikan perhatian untuk mengevaluasi secara berkala tentang keberlanjutan sistem yang mengintegrasikan teknologi digital berbasis internet agar dapat menjangkau keluhan individu dalam suatu instansi (industri/organisasi dan pendidikan) serta membantu memberikan solusi yang tepat.

\section{Bagi Organisasi dan Institusi Pendidikan}

Membuat sistem, kebijakan atau aturan yang mendorong individu untuk dapat mempertahankan pengalaman positif terhadap penggunaan teknologi digital berbasis-internet. Pengalaman positif mengarahkan pengguna untuk tidak resisten terhadap perubahan. Dalam konteks industri dapat mempertimbangkan pelatihan berkelanjutan untuk menambah keterampilan penggunaan teknologi dalam penilaian kerja. Pada konteks pendidikan, guru dan dosen dapat memanfaatkan dan mengintegrasikan media teknologi dalam sistem pembelajaran.

Bagi pemangku kebijakan (khususnya di perusahaan), penting untuk memperhatikan tingkat kemampuan literasi digital dengan membuat iklim kerja yang mendukung proses pembelajaran (organizational learning). Seperti membuat tim khusus yang ahli dalam penguasaan teknologi sehingga mampu berperan sebagai mentor untuk memfasilitasi individu yang lain dalam menggunakan teknologi digital secara lebih optimal. Sosialisasi literasi secara teknikal diperlukan untuk mendukung pengalaman positif penggunaan teknologi digital berbasis internet. 


\section{DAFTAR PUSTAKA}

Alvermann, D. E. (2004). Media, information communication technologies, and youth literacies: A cultural studies perspective. American Behavioral Scientist, 48(1), 78-83. https://doi.org/10.1177/0002764204267271

Ariyanti, S. (2013). Studi pengukuran digital divide di Indonesia. Buletin Pos dan Komunikasi, $11(4), 281-292$

Asosiasi Pengelenggara Jasa Internet Indonesia \& Teknopreneur. (2017). Survei Infografis Penetrasi dan Perilaku Pengguna Internet Indonesia.

Cran, C. (2010). 101 Ways to Make Generation X, Y, Zoomers Happy at Works. Vancouver Synthesis at Work Inc

Cummings, T.G., \& Worley, C.G. (2008).Organization Development and Change (9th edition). USA: South Western Cengage Learning

Elmore, T. (2014). How Generation Z Differs from Generation $Y$. Retrived July 01, 2015, https://growingleaders.com/generation-z-differs-generation-y

Flood, C. (2016). The online workplace. In I. Connolly, M. Palmer, H. Barton, \& G. Kirwan (Eds.), An Introduction to Cyberpsychology (pp. 181-192). New York: Routledge.

Glaser, B.G., Strauss, A.L. (1967). The Discovery of Grounded Theory: Strategies for Qualitative Research. New York: Aldine

Gurung, B., \& Rutledge, D. (2014). Digital learners and the overlapping of their personal and educational digital engagement. Computers and Education, 77, 91-100. https://doi. org/10.1016/j.compedu.2014.04.012

Hanaysha, J. R. (2017). Impact of social media marketing, price promotion, and corporate social responsibility on customer satisfaction. Jindal Journal of Business Research, 6(2), 132-145. https://doi.org/10.1177/2278682117715359

Judi, H. M., Ashaari, N. S., Zin, N. A. M., \& Yusof, Z. M. (2013). Framework of ICT impact on adolescent. Procedia Technology, 11, 1034-1040. https://doi.org/10.1016/j. protcy.2013.12.291

Kementerian Perindustrian Republik Indonesia. (2018). Empat Strategi Indonesia Masuk Revolusi Industri Keempat. Retrieved September 28, 2018, from http://www.kemenperin. go.id/artikel/17565/Empat-Strategi-Indonesia-Masuk-Revolusi-Industri-Keempat

Kementerian Riset, Teknologi, dan Pendidikan Tinggi Republik Indonesia (2018). Menristekdikti: Perlu Reorientasi Kurikulum untuk Meningkatkan inovasi Perguruan Tinggi di era Revolusi Industri 4.0 September 28, 2018, from https://ristekdikti.go.id/ kabar/menristekdikti-perlu-reorientasi-kurikulum-untuk-meningkatkan-inovasiperguruan-tinggi-di-era-revolusi-industri-4-0/

Mohammadyari, S., \& Singh, H. (2015). Understanding the effect of e-learning on individual performance: The role of digital literacy. Computers and Education, 82, 11-25. https:// doi.org/10.1016/j.compedu.2014.10.025

Kreitner, R., \& Kinichi, A. (2007). Organizational Behavior, 5th edition. NewYork, NY: McGraw-Hill 
La Kahija, Y.F. (2017). Penelitian Fenomenologis: Jalan Memahami Pengalaman Hidup. Yogyakarta: PT Kanisius

Park, S. (2012). Dimensions of digital media literacy and the relationship with social exclusion. Media International Australia, (142), 87-100. https://doi. org/10.1177/1329878X1214200111

Puspitasari, L., \& Ishii, K. (2016). Digital divides and mobile internet in Indonesia: impact of smartphones. Telematics and Informatics, 33(2), 472-483. https://doi.org/10.1016/j. tele.2015.11.001

Ramdhani, N., \& Wiradhany, W. (2013). Indonesian digital natives ICT usage pattern study across different age groups. In K. Mustofa et al. (Eds). ICT-EurAsia 2013, LNCS 7804 (pp. 152-161). IFIP International Federation for Information Processing.

Syarifuddin. (2014). Literasi teknologi informasi dan komunikasi. Jurnal Penelitian Komunikasi, 17(2), 153-164.

Takenouchi, T. (2004). A consideration on the concept of information literacy; Is it really "necessary for all"?. International Journal of Information Ethics, 2, 1-6.

Techataweewan, W., \& Prasertsin, U. (2018). Development of digital literacy indicators for Thai undergraduate students using mixed method research. Kasetsart Journal of Social Sciences, 39(2), 215-221. https://doi.org/10.1016/j.kjss.2017.07.001

Thomas, K. J., \& Akdere, M. (2013). Social media as collaborative media in workplace learning. Human Resource Development Review, 12(3), 329-344. https://doi. org/10.1177/1534484312472331

Van Aalst, J., Hing, F. W., May, L. S., \& Yan, W. P. (2007). Exploring information literacy in secondary schools in Hong Kong: A case study. Library and Information Science Research, 29(4), 533-552. https://doi.org/10.1016/j.lisr.2007.06.004

Wahid, F., Ramdhani, N., \& Wiradhany, W. (2013). More gaining and less gaming? The internet use in Indonesia after one decade. Recent Trends in Social and Behaviour Sciences - Proceedings of the 2nd International Congress on Interdisciplinary Behavior and Social Sciences 2013, ICIBSoS 2013, (November), 217-222. https://doi.org/10.1201/ b16658-40 